\title{
The Neuronal Code(s) of the Cerebellum
}

\author{
Detlef H. Heck, ${ }^{1}$ Chris I. De Zeeuw, ${ }^{2,3}$ Dieter Jaeger, ${ }^{4}$ Kamran Khodakhah, ${ }^{5}$ and Abigail L. Person ${ }^{6}$ \\ ${ }^{1}$ Department of Anatomy and Neurobiology, University of Tennessee Health Science Center, Memphis, Tennessee 38163, ${ }^{2}$ Department of Neuroscience, \\ Erasmus MC, 3000 DR Rotterdam, The Netherlands, ${ }^{3}$ Netherlands Institute for Neuroscience, Royal Academy of Arts and Sciences, 1105 BA Amsterdam, \\ The Netherlands, ${ }^{4}$ Department of Biology, Emory University, Atlanta, Georgia 30322, 5 Department of Neuroscience, Albert Einstein College of Medicine, \\ Bronx, New York 10461, and ${ }^{6}$ Department of Physiology and Biophysics, University of Colorado School of Medicine, Aurora, Colorado 80045
}

Understanding how neurons encode information in sequences of action potentials is of fundamental importance to neuroscience. The cerebellum is widely recognized for its involvement in the coordination of movements, which requires muscle activation patterns to be controlled with millisecond precision. Understanding how cerebellar neurons accomplish such high temporal precision is critical to understanding cerebellar function. Inhibitory Purkinje cells, the only output neurons of the cerebellar cortex, and their postsynaptic target neurons in the cerebellar nuclei, fire action potentials at high, sustained frequencies, suggesting spike rate modulation as a possible code. Yet, millisecond precise spatiotemporal spike activity patterns in Purkinje cells and inferior olivary neurons have also been observed. These results and ongoing studies suggest that the neuronal code used by cerebellar neurons may span a wide time scale from millisecond precision to slow rate modulations, likely depending on the behavioral context.

\section{Introduction}

The cerebellum has long been regarded as a purely sensorimotorrelated structure, crucial for the precise temporal coordination of body, limb, and eye movements and the learning and fine-tuning of motor skills. Electrophysiological investigations of the cerebellar cortical principal neurons, the Purkinje cells, and their postsynaptic targets, the neurons in the cerebellar nuclei $(\mathrm{CN})$ and vestibular nuclei, revealed strong representations of a wide variety of sensory and motor events (Ito, 1984; Strata, 1989) in the presence of high sustained spike rates (Thach, 1972).

Extracellular single-unit recordings, particularly those conducted in awake and behaving nonhuman primates, have established that Purkinje cell simple spike rates represent a variety of variables related to the control of eye, head, and limb movements. Encoded variables include the direction of limb movements (e.g., Harvey et al., 1977; Thach, 1978; Fortier et al., 1989; Smith et al., 1993) and limb movement velocity or speed (Coltz et al., 1999; Roitman et al., 2005). Studies of arm movement dynamics provided evidence that Purkinje cell simple spike activity represents both forward prediction and feedback error-related signals, consistent with an involvement of the cerebellum in the prediction of expected sensorimotor states and the detection and correction of motor errors (Pasalar et al., 2006; for a recent review, see Ebner et

\footnotetext{
Received June 28, 2013; revised Aug. 28, 2013; accepted Aug. 29, 2013.

This work was supported by the National Institutes of Health Grant NS067201 to D.J., Grants NS060887 and NS063009 to D.H.H., Grants NS050808, NS079750, and NS050808 to K.K., Dutch Organization for Medical Sciences (ZonMw) to C.I.D.Z., Life Sciences, Senter (NeuroBasic), and the ERC-advanced, CEREBNET, and C7 programs of the European Community, and an Alfred P. Sloan Foundation and Klingenstein Foundation fellowship to A.P. The content of this publication is solely the responsibility of the authors and does not necessarily represent the official views of the National Institutes of Health.

The authors declare no competing financial interests.

Correspondence should be addressed to Dr. DetlefH. Heck, Department of Anatomy and Neurobiology, University of Tennessee Health Science Center, 855 Monroe Avenue, Room 409, Memphis, TN 38163. E-mail: dheck@uthsc.edu. DOI:10.1523/JNEUROSCI.2759-13.2013

Copyright $\odot 2013$ the authors $\quad 0270-6474 / 13 / 3317603-07 \$ 15.00 / 0$
}

al., 2011; Popa et al., 2012, 2013). Another large body of literature from primate experiments describes the role of the cerebellum in controlling voluntary eye movements and the coordination of compensatory eye and head movements (Robinson and Fuchs, 2001; Voogd and Barmack, 2006; Voogd et al., 2012). Relevant to the integration of converging Purkinje cell inputs in $\mathrm{CN}$ neurons, Thier et al. (2000) reported an example of population coding in the cerebellum, showing that the duration of saccades is represented well in the simple spike activity of populations of Purkinje cells, but less so in individual cells.

When it became known that Purkinje cells inhibited CN neurons (Ito et al., 1964), a plausible hypothesis was that increased activity in cerebellar cortical Purkinje cells would decrease cerebellar output by inhibiting the excitatory $\mathrm{CN}$ neurons. That notion was tested in a challenging in vivo experiment conducted by McDevitt et al. (1987). Their experiment involved simultaneous recordings from Purkinje cells and their presumed postsynaptic target neurons in the $\mathrm{CN}$ and revealed that Purkinje cell and $\mathrm{CN}$ spike rate fluctuations were rather similar and did not show consistent reciprocal changes expected from the converging Purkinje to $\mathrm{CN}$ neuron inhibition. These findings suggested that other inputs to the $\mathrm{CN}$ neurons in addition to Purkinje cells are involved in the control of cerebellar output. It had been known that mossy fibers produced collateral projections to the $\mathrm{CN}$ (Ito, 1984), but the percentage of fibers sending collaterals was unknown. Shinoda et al. (1992) traced 40 individual mossy fiber axons from the pontine nuclei to the cerebellum and showed that approximately half produced collateral branches terminating in the dentate nucleus. Thus, $\sim 50 \%$ of mossy fibers provide excitatory inputs to $\mathrm{CN}$ neurons via collaterals, competing with the inhibitory inputs from Purkinje cells, which were in turn activated indirectly (via parallel fibers) by the same mossy fibers (Fig. 1). At the same time, mossy fiber activity is relayed via parallel fibers to inhibitory interneurons in the cerebellar cortex, which inhibit Purkinje cells (Dizon and Khodakhah, 2011). This feedforward inhibition likely also contributes to the comodula- 
tion of Purkinje cell-CN activity. Another important variable in cerebellar corticonuclear interaction is the possible coordination of spike activity within a population of Purkinje cells converging on the same $\mathrm{CN}$ neuron. In vitro and modeling studies have shown that inhibitory inputs synchronized across a population of Purkinje cells can actually increase firing rates in $\mathrm{CN}$ neurons (Gauck and Jaeger, 2000; Person and Raman, 2012). A special relationship exists between the cerebellum and the inferior olive, with each Purkinje cell receiving a powerful excitatory climbing fiber input from a single inferior olive neuron, whereas the same climbing fiber often provides a collateral to the $\mathrm{CN}$ neuron that receives input from the corresponding Purkinje cell (Palay and Chan-Palay, 1974; De Zeeuw et al., 2011). In turn, inhibitory neurons in the $\mathrm{CN}$ send projections to the inferior olive (De Zeeuw et al., 1988). The olivocerebellar projections are organized in zones, and evidence suggests that neuronal coding varies between zones (Oscarsson, 1979; Apps and Garwicz, 2000; Zhou et al., 2013). Scattered evidence from electrophysiological experiments of isolated parts of the cerebellum suggests a functional relevance of zebrin II parasagittal zones in terms of behavior-related Purkinje cell simple spike activity and of complex spike synchrony (Sugihara et al., 2007; Bosman et al., 2010; Ebner et al., 2012; Graham and Wylie, 2012), but a systematic evaluation of the complete cerebellum remains to be shown (Zhou et al., 2013).

This symposium review highlights essential aspects of current approaches to the question of neuronal coding in the cerebellum, pursued in the laboratoriess of the individual contributors.

\section{Synchrony of Purkinje cells can elicit time-locked spiking in the cerebellar nuclei}

Of critical importance to understanding information processing in the cerebellum is solving the transfer function between Purkinje cells and their target neurons in the cerebellar nuclei. Because Purkinje cells are tonically active and inhibitory onto CN neurons (Ito and Yoshida, 1966; Ito et al., 1970) and because $\mathrm{CN}$ neurons are themselves autonomous pacemakers (Thach, 1968; Raman et al., 2000), it is often assumed that cerebellar nuclear neurons simply invert signals from Purkinje cells. Data collected in both behaving monkeys and decerebrate cats have been equivocal in supporting these assumptions, however. For example, a majority of both Purkinje cells and CN neurons increase their firing rates during stepping and cue-initiated movements (Thach, 1970a, b; Armstrong and Edgley, 1984a, b). Furthermore, putatively connected pairs of Purkinje and nuclear neurons recorded simultaneously do not show clear reciprocal relationships in activity levels (McDevitt et al., 1987).
$\mathbf{A}$
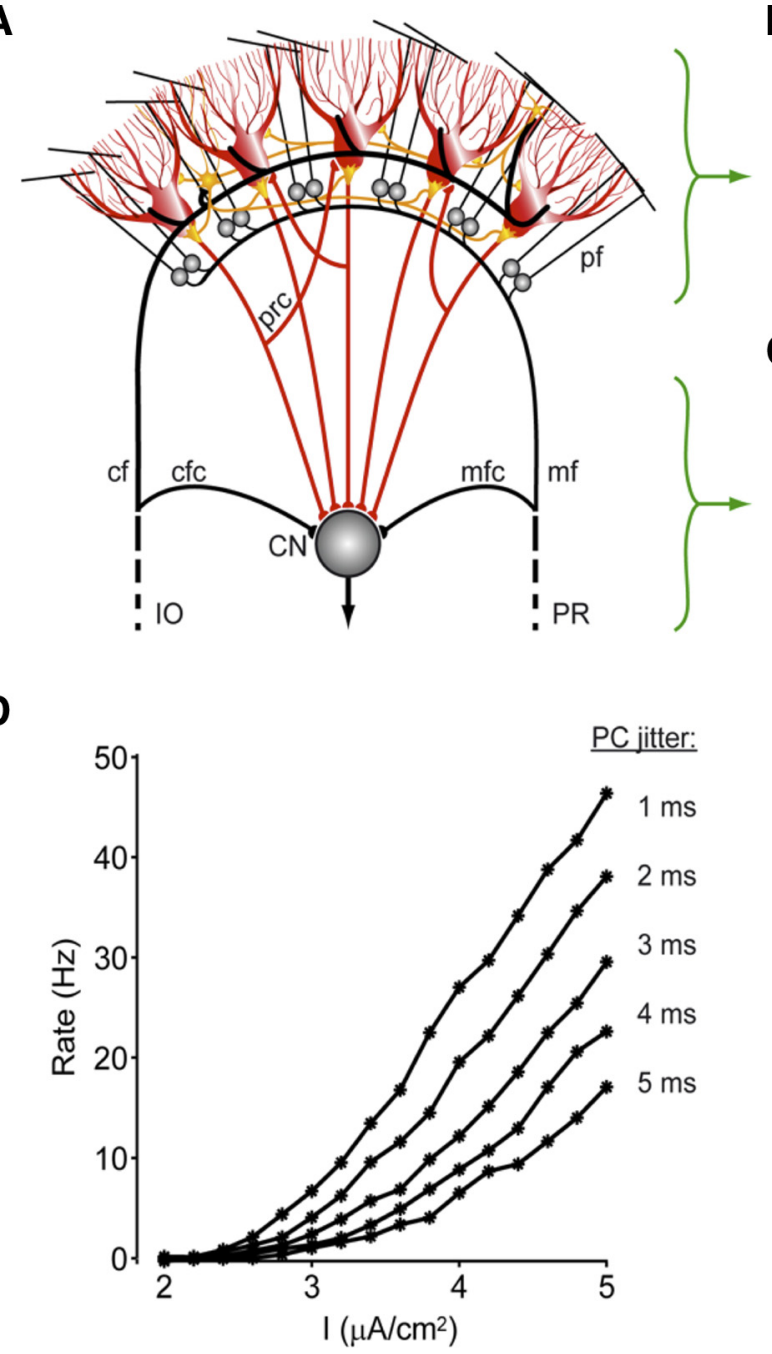

B

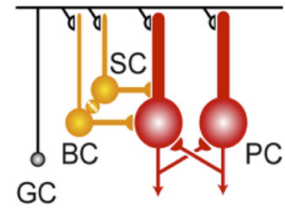

C

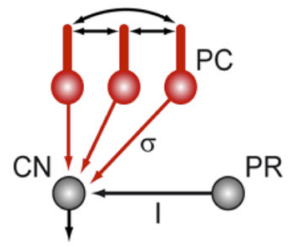

Figure 1. Scheme indicating how activity of Purkinje cells in the cerebellar cortex may influence activity in the cerebellar nuclei. $A$, The cerebellar cortex receives main excitatory inputs (black) from the inferior olive (I0) and pontine regions (PR) and provides via the Purkinje cell axons an inhibitory feedback (red) to the CN. Whereas the external I0 and PR signals, which enter the cerebellum via the climbing fibers ( $\mathrm{cf}$ ) and the mossy fiber (mf)-parallel fiber (pf) pathway, are all excitatory, the local transmissions by the axons of the molecular layer interneurons (yellow) and recurrent collaterals (prc) of the Purkinje cells (red) are all inhibitory. mfc, Mossy fiber collaterals; cfc, climbing fiber collaterals. The local Golgi cell inhibition of granule cells (GC) is not depicted in this drawing. $B$, Molecular layer interneurons, that is, basket cells (BC) and stellate cells (SC), are coupled by gap junctions (yellow), whereas Purkinje cells (PC) can influence one another via recurrent collaterals. C, Firing rate gain in the $\mathrm{CN}$ after excitation (I) by the Purkinje cells. The $\mathrm{PC}$ spike-time dispersion $(\sigma)$ is inversely related to the synchrony of this network oscillation. $\boldsymbol{D}$, The $C N$ firing rate versus $\mathrm{mfc}$ input current (I) plots are shown for different values of the PC jitter. As the jitter is decreased from 5 to $1 \mathrm{~ms}$ (from bottom $\mathrm{PC}$ synchrony might be one of the potential mechanisms by which high-frequency oscillations in the cerebellar cortex exert their effects (modified from De Zeeuw et al., 2008).

These findings suggested an incomplete understanding of corticonuclear integration that prompted a recent reexamination of a set of basic properties of the corticonuclear circuit, including unitary Purkinje-to-nuclear synaptic strength and kinetics; intrinsic nuclear firing rates; and Purkinje-to-nuclear convergence ratios (Hoebeek et al., 2010; Person and Raman, 2012; Witter et al., 2013). Unitary synaptic strength was strong, averaging $9 \mathrm{nS}$, suggesting a powerful inhibitory connection between Purkinje and $\mathrm{CN}$ cells. Further, at near physiological temperatures, the kinetics of these inhibitory synaptic currents were remarkably fast, with decay time constants averaging $2.5 \mathrm{~ms}$. Together, these synaptic properties indicate a powerful but brief influence of Pur- 
kinje cells onto the CN. Intrinsic firing rates measured in on-cell recordings were significantly higher in older animals, averaging $90 \mathrm{~Hz}$ compared with $\sim 20 \mathrm{~Hz}$ measured in younger animals more typically recorded in vitro. Finally, combining anatomical and physiological measurements, the convergence ratio of Purkinje to nuclear neurons was estimated to be on the order of 50 (Person and Raman, 2012).

These basic parameters of the corticonuclear circuit were then used in a dynamic clamp system to explore corticonuclear integration, mimicking in vivo-like Purkinje inputs to the $\mathrm{CN}$. One key finding from these experiments was that nuclear neurons are exquisitely sensitive to synchronous inhibitory input: Nuclear neurons fired faster and with time-locked spikes in the face of synchronous Purkinje input, even when the fraction of synchronous inputs was as low as $5 \%$ of the convergent population (Person and Raman, 2012).

These data shed light on the potential function of synchronous Purkinje cell simple spike activity that has been observed in vivo by numerous groups (Bell and Grimm, 1969; Bell and Kawasaki, 1972; MacKay and Murphy, 1976; Ebner and Bloedel, 1981; De Zeeuw et al., 1997; Shin and De, 2006; Heck et al., 2007; de Solages et al., 2008; Bosman et al., 2010; Wise et al., 2010). If synchronously active Purkinje cells converged onto a common target cell, it would be predicted that the postsynaptic neurons would fire both faster and with time-locked spikes (Fig. 1) (Gauck and Jaeger, 2000; De Zeeuw et al., 2008; Person and Raman, 2012). Indeed, artificially imposing synchrony onto a population of Purkinje cells with electrical stimulation in vivo elicited phase-locked spiking in nuclear neurons. In support of this idea, nuclear spiking shows phase locking to local field potentials and cortical oscillations during movement (Holdefer et al., 2000; Courtemanche et al., 2002; Courtemanche and Lamarre, 2005), illustrating precise spike timing in a nonmanipulated environment.

\section{Linear information processing by the cerebellar cortex}

A remarkable feature of movement is the precision with which it is accomplished given the relative imprecision of the neuronal elements that encode it. Curiously, despite its prominent role in motor coordination, the considerable computation that is performed by the cerebellar circuitry introduces little noise in motor performance. An elegant demonstration of this astonishing feature of the cerebellar circuitry was provided by a careful study of smooth eye pursuit by Medina and Lisberger (2007). During smooth eye pursuit, the average firing rate of individual Purkinje cells can be described by weighted linear combination of three movement-related parameters: eye velocity, acceleration, and position (Shidara et al., 1993). An analysis of the correlation between variation in the instantaneous firing rate of individual Purkinje cells with the precision of smooth eye pursuit from trial to trial revealed that, during each individual trial, a large fraction of the variation in the eye movement, as pursuit is initiated, could be accounted for by the variation in the common cerebellar input signals (Medina and Lisberger, 2007). This is astonishing given the fact that Purkinje cells are not particularly precise in encoding the strength of their excitatory synaptic inputs (Walter and Khodakhah, 2009), begging the question of how the noise inherent in the activity of individual Purkinje cells is minimized to improve their overall signal-to-noise ratio. An answer to this question might be provided by the organization of the cerebellar circuitry: tens of Purkinje cells converge onto neurons within the cerebellar nuclei (Person and Raman, 2012) (in the case of smooth eye pursuit, mainly onto the vestibular nuclei). As pos- tulated by Eccles (1973), by reducing the magnitude of the uncorrelated noise in the activity of individual Purkinje cells (Walter and Khodakhah, 2009), this convergence might provide the substrate for a simple averaging mechanism to improve the signal-to-noise ratio of the common information encoded by a population of Purkinje cells. Nuclei neurons can accomplish this by either averaging the rate code of Purkinje cells that converge on them (Walter and Khodakhah, 2009) or, in principle, by extracting the timing of correlated activity in the same population of Purkinje cells (Person and Raman, 2012). Although plausible, it has not yet been established that cerebellar nuclei neurons do indeed improve the signal-to-noise ratio of the information encoded by individual Purkinje cells. To directly demonstrate an increase in the signal-to-noise ratio of the information encoded by nuclei neurons compared with that of Purkinje cells, the variation in the activity of each neuron type can be examined when the same command input is repeatedly applied to a population of Purkinje cells. One approach is to use optogenetics to repeatedly drive the activity of Purkinje cells with sinusoidal inputs to mimic what is seen during vestibulo-ocular reflex or a smooth eye pursuit task. Variation in the instantaneous firing rate of Purkinje cells monitored in vivo can then be compared with that in the cerebellar nuclei in response to the same sinusoidal command inputs. Under these conditions, it is found that the firing rate of cerebellar nuclei is modulated primarily reciprocal to that seen in the Purkinje cells (K.K., unpublished observations; for nonsinusoidal inputs, see also Witter et al., 2013). Moreover, in support of the notion that nuclear neurons average Purkinje cell inputs, preliminary data suggest that, from trial to trial, cerebellar nuclei manifest smaller variations in their firing rate compared with Purkinje cells. These studies have the potential to quantitatively assess the extent to which the cerebellar circuitry improves the signal-to-noise ratio of the information encoded by individual Purkinje cells by extracting the common information in a population of Purkinje cells. It is important to note, however, that, in addition to receiving convergent information from Purkinje cells, cerebellar nuclei also receive direct collateral inputs from mossy and climbing fibers. It remains to be established whether the cerebellum implements a mechanism to minimize the noise associated with these inputs.

\section{Purkinje cells and their target neurons operate at different coding schemes depending on the olivocerebellar module involved}

The output of the cerebellar cortex is provided by a layer of Purkinje cells that deliver inhibitory projections onto cells in the cerebellar nuclei, which in turn represent the final output of the cerebellum (Fig. 1) (De Zeeuw et al., 2011). The overall physiological characteristics of Purkinje cells have traditionally been considered to be homogeneous (Ito, 1984; but see Wadiche and Jahr, 2005; Graham and Wylie, 2012). Recently, systematic ubiquitous recordings in the cerebellum of awake mice have indicated that spiking activity of Purkinje cells, the sole output cells of the cerebellar cortex, differs between olivocerebellar modules when animals are at rest (Zhou et al., 2013). At rest, simple spike and complex spike frequencies covary concomitantly in that complex spike firing frequency is usually high when the simple spike firing frequency is high and vice versa (for reciprocity during modulation, see also Badura et al., 2013). Indeed, the simple spike frequency at rest appears to be predominantly determined by the intrinsic activity of Purkinje cells, which might correlate with the differential expression and distribution of relevant conductances and proteins involved in spike generation, energy consumption, 
and glutamate clearance (Kim et al., 2012). The level of complex spike activity follows that of the simple spikes due to the Purkinje cell projections to the GABAergic cells in the cerebellar nuclei that inhibit the olivary neurons establishing the baseline climbing fiber activity (Chen et al., 2010; Witter et al., 2013). Thus, our preliminary results indicate that different olivocerebellar modules operate at different frequencies, which depend on the intrinsic constitution of Purkinje cells, and that this property is relevant for all cerebellar functions (Zhou et al., 2013).

To further test the coding schemes of the different olivocerebellar modules functioning at different firing frequencies at rest, we studied the modules controlling adaptation of the vestibuloocular reflex and eyeblink conditioning (Van Der Giessen et al., 2008; Gao et al., 2012). Our studies on the flocculus of the vestibulocerebellum indicated that its Purkinje cells fire indeed predominantly at low firing frequency at rest, that they are more prone and sensitive for potentiation than depression during visuo-vestibular training (Schonewille et al., 2010, 2011), and that their capacity for motor learning depends on the modulation amplitude of Purkinje cell's simple spike activity relative to the baseline firing frequency at rest (Galliano et al., 2013). Moreover, comparison of the timing of Purkinje cell's simple spike activity with that of neurons in the vestibular nuclei that do and do not receive input from these Purkinje cells indicates that Purkinje cells of the vestibulocerebellum are well designed to manipulate the timing of floccular target cells through rate coding (De Zeeuw et al., 1995). In addition, the regularity of simple spike firing may contribute to the consolidation of visuo-vestibular learning (Wulff et al., 2009; Galliano et al., 2013). In contrast, our preliminary studies on Purkinje cells in lobulus simplex of the neocerebellum indicate that its Purkinje cells fire at higher firing frequency at rest (Van Der Giessen et al., 2008) and that they are more prone and sensitive for suppression than potentiation during eyeblink conditioning (Ten Brinke et al., 2013). Moreover, the target neurons of Purkinje cells in the anterior interposed cerebellar nucleus, which includes the eyeblink region, show prominent rebound activity after optogenetic stimulation of the Purkinje cells in a dosage-dependent fashion and this rebound occurs at the proper moment so as to enhance the conditioned response (Witter et al., 2013). Thus, Purkinje cells of different olivocerebellar modules appear to engage different encoding strategies dedicated for the type of behavior they control, and these strategies probably reflect the temporal dynamics of the behavior involved.

\section{Coding of rhythmic movements through common rate modulation}

Animals perform a number of rhythmic movements, such as breathing, licking, whisking, chewing, etc., which are vital for survival and are likely to involve the cerebellum. There is an obvious need for a precisely timed coordination between some of these rhythmic behaviors. For example, to prevent fluids from entering the airways and lungs, fluid licking, breathing, and swallowing rhythms have to be well coordinated (Welzl and Bures, 1977; Weijnen et al., 1984). Such stereotypic, rhythmic movements are generally driven by separate brainstem central pattern generator circuits, some of which have more or less well-known locations in the brainstem (Travers et al., 1997; Feldman et al., 2003; Cramer et al., 2007). A recent anatomical study suggested that neurons in the medial cerebellar nuclei project directly to brainstem sites thought to contain those central pattern generator circuits (Lu et al., 2013). In vivo studies in rodents have shown that licking, breathing, and whisking are widely represented in
Purkinje cell and CN spiking activity (Welsh et al., 1995; Hayar et al., 2006; Bosman et al., 2010; Bryant et al., 2010; Cao et al., 2012b; $\mathrm{Lu}$ et al., 2013). A role of the cerebellum in controlling or coordinating such rhythmic movements is further supported by studies in genetic mouse models of brain disorders involving cerebellar neuropathology, such as autism spectrum disorders. Mouse models of Angelman, fragile X, and Potocki-Lupski syndrome show deficits in fluid licking behavior (Heck et al., 2008; Roy et al., 2011; Heck et al., 2012). Furthermore, rhythmic modulation of spike activity phase-locked to respiratory behavior is present in mossy fiber activity (D.H.H., unpublished data). Given the general cerebellar involvement in motor coordination, a natural role for the cerebellum in these behaviors would be the coordination between the motor rhythms.

Electrophysiological recordings from awake behaving mice revealed some aspects of how rhythmic behaviors are encoded in spike trains of cerebellar neurons and how the modulation of the cerebellar nuclear spike activity could be controlled by mossy fiber and Purkinje cell inputs. Previous evidence suggested that pauses in Purkinje cell activity could constitute a special mechanism of cerebellar corticonuclear transfer (Albus, 1971; Gauck and Jaeger, 2000; De Schutter and Steuber, 2009; Witter et al., 2013). Analysis of the relation between pauses in Purkinje cell spiking and rhythmic behaviors showed, however, that a model of stochastic spike interval distributions reproducing behaviorrelated rate fluctuations could fully explain the relation between pauses and behavior, showing that, at least with respect to rhythmic orofacial movements, pauses are not independently generated elements of Purkinje cell neuronal coding (Cao et al., 2012b). The same study did not reveal any millisecond precision in the simple spike activity between single-unit Purkinje cells recorded along the sagittal or transverse axis of the cerebellar vermis. Instead, a rate-based analysis of simple spike activity provided evidence for an optimal representation of rhythmic behaviors in the rate fluctuations of mossy fiber, Purkinje cell, and CN spike trains, rather than the exact times of spike firing (Cao et al., 2012a). Convolving spike times with increasingly wider Gaussian kernels (i.e., larger $\sigma$ values) to produce instantaneous firing rate functions with various widths of the Gauss kernels revealed that the strongest correlation between rhythmic behavior and simple spike rate modulation was seen when Gauss kernels with $\sigma$ values between $\sim 10$ and $125 \mathrm{~ms}$ were used. Importantly, when such smoothed rate functions were compared across pairs of simultaneously recorded Purkinje cells, strong rate change correlations were seen across cells for slow rate fluctuations $(\sigma=250 \mathrm{~ms})$ (D.H.H., unpublished data). This suggests that joint rate change functions across populations of Purkinje cells could be a significant driver of rate changes in the deep nuclei. A biophysically detailed model of a cerebellar nucleus neuron (Steuber et al., 2011) was used to determine how $\mathrm{CN}$ neuron spiking would be affected by population Purkinje cell input with different degrees of rate correlation. Indeed, rate correlations between Purkinje cells turned out to be a strong determinant of $\mathrm{CN}$ spike modulation, and the level of rate comodulation seen between Purkinje cells could account for the depth of rate modulation observed in $\mathrm{CN}$ recordings (D.J. unpublished data). Interestingly, simultaneous recordings of Purkinje cells and $\mathrm{CN}$ neurons showed time-varying positive and negative rate correlations (D.H.H., unpublished data), suggesting that at different times either mossy fiber or Purkinje cell rate modulation might dominate $\mathrm{CN}$ rate changes. Overall, the current evidence points toward a rate code for the representation of rhythmic behaviors in the cerebellum, which can be effectively transmitted between 
Purkinje cells and $\mathrm{CN}$ neurons, but also between mossy fibers and $\mathrm{CN}$ neurons. Hence, synaptic plasticity rules that favor strengthening synapses of populations of rate correlated inputs at particular behavioral events would be a key factor in cerebellar coding. Interestingly, plasticity rules at the level of the $\mathrm{CN}$ are indeed strongly dependent on temporal patterns of hyperpolarization and depolarization (Pugh and Raman, 2009; Person and Raman, 2010), which would be expected with rate-correlated inputs.

\section{Summary}

In conclusion, recent years have seen renewed interest in the function of the cerebellum, and much progress has been made toward understanding the neuronal coding of sensory and motor events in Purkinje cells and cerebellar nuclear and vestibular neurons. Among the important new insights are findings of zonal specificity of Purkinje cell and $\mathrm{CN}$ neuronal firing, the relevance of population dynamics, including precise spike synchrony and correlated slow rate fluctuations. However, many questions remain to be answered, in particular with respect to the relative contributions of Purkinje and mossy fiber inputs to $\mathrm{CN}$ spike firing. Neurogenetic tools, which allow cell type-specific manipulations of neuronal activity and synaptic transmission, may now provide the opportunity to address these questions experimentally with unprecedented precision. This symposium review focused implicitly on the sensorimotor aspects of cerebellar coding, but there is increasing evidence for a role of the cerebellum in cognition and emotion (Schmahmann and Caplan, 2006; Koziol et al., 2011; Stoodley, 2011; Fatemi et al., 2012; Heck and Howell, 2013). A comprehensive understanding of the cerebellar neuronal code will ultimately have to include such nonmotor aspects as well. We have just begun to scratch the surface of cerebellar, neuronal encoding mechanisms (Mittleman et al., 2008; Rogers et al., 2011, 2013); hopefully, with the advent of new technologies, the upcoming decades will allow us to unravel them at both sensorimotor levels and beyond.

\section{References}

Albus JS (1971) A theory of cerebellar function. Math Biosci 10:25-61. CrossRef

Apps R, Garwicz M (2000) Precise matching of olivo-cortical divergence and cortico-nuclear convergence between somatotopically corresponding areas in the medial $\mathrm{C} 1$ and medial $\mathrm{C} 3$ zones of the paravermal cerebellum. Eur J Neurosci 12:205-214. CrossRef Medline

Armstrong DM, Edgley SA (1984a) Discharges of Purkinje cells in the paravermal part of the cerebellar anterior lobe during locomotion in the cat. J Physiol 352:403-424. Medline

Armstrong DM, Edgley SA (1984b) Discharges of nucleus interpositus neurones during locomotion in the cat. J Physiol 351:411-432. Medline

Badura A, Schonewille M, Voges K, Galliano E, Renier N, Gao Z, Witter L, Hoebeek FE, Chédotal A, De Zeeuw CI (2013) Climbing fiber input shapes reciprocity of Purkinje cell firing. Neuron 78:700-713. CrossRef Medline

Bell CC, Grimm RJ (1969) Discharge properties of Purkinje cells recorded with single and double microelectrodes. J Neurophysiol 32:1044-1055. Medline

Bell CC, Kawasaki T (1972) Relations among climbing fiber responses of nearby Purkinje cells. J Neurophysiol 35:155-169. Medline

Bosman LW, Koekkoek SK, Shapiro J, Rijken BF, Zandstra F, van der Ende B, Owens CB, Potters JW, de Gruijl JR, Ruigrok TJ, De Zeeuw CI (2010) Encoding of whisker input by cerebellar Purkinje cells. J Physiol 588: 3757-3783. CrossRef Medline

Bryant JL, Boughter JD, Gong S, LeDoux MS, Heck DH (2010) Cerebellar cortical output encodes temporal aspects of rhythmic licking movements and is necessary for normal licking frequency. Eur J Neurosci 32:41-52. CrossRef Medline

Cao Y, Maran SK, Jaeger D, Heck DH (2012a) Representation of behaviour in the cerebellum: spike rate modulation vs. spike timing. Soc Neurosci Abstract 477.07.

Cao Y, Maran SK, Dhamala M, Jaeger D, Heck DH (2012b) Behavior related pauses in simple spike activity of mouse Purkinje cells are linked to spike rate modulation. J Neurosci 32:8678-8685. CrossRef Medline

Chen X, Kovalchuk Y, Adelsberger H, Henning HA, Sausbier M, Wietzorrek G, Ruth P, Yarom Y, Konnerth A (2010) Disruption of the olivocerebellar circuit by Purkinje neuron-specific ablation of BK channels. Proc Natl Acad Sci U S A 107:12323-12328. CrossRef Medline

Coltz JD, Johnson MT, Ebner TJ (1999) Cerebellar Purkinje cell simple spike discharge encodes movement velocity in primates during visuomotor arm tracking. J Neurosci 19:1782-1803. Medline

Courtemanche R, Lamarre Y (2005) Local field potential oscillations in primate cerebellar cortex: synchronization with cerebral cortex during active and passive expectancy. J Neurophysiol 93:2039-2052. CrossRef Medline

Courtemanche R, Pellerin JP, Lamarre Y (2002) Local field potential oscillations in primate cerebellar cortex: modulation during active and passive expectancy. J Neurophysiol 88:771-782. Medline

Cramer NP, Li Y, Keller A (2007) The whisking rhythm generator: a novel mammalian network for the generation of movement. J Neurophysiol 97:2148-2158. CrossRef Medline

De Schutter E, Steuber V (2009) Patterns and pauses in Purkinje cell simple spike trains: experiments, modeling and theory. Neuroscience 162:816826. CrossRef Medline

de Solages C, Szapiro G, Brunel N, Hakim V, Isope P, Buisseret P, Rousseau C, Barbour B, Léna C (2008) High-frequency organization and synchrony of activity in the Purkinje cell layer of the cerebellum. Neuron 58:775-788. CrossRef Medline

De Zeeuw CI, Holstege JC, Calkoen F, Ruigrok TJ, Voogd J (1988) A new combination of WGA-HRP anterograde tracing and GABA immunocytochemistry applied to afferents of the cat inferior olive at the ultrastructural level. Brain Res 447:369-375. CrossRef Medline

De Zeeuw CI, Wylie DR, Stahl JS, Simpson JI (1995) Phase relations of Purkinje cells in the rabbit flocculus during compensatory eye movements. J Neurophysiol 74:2051-2064. Medline

De Zeeuw CI, Koekkoek SK, Wylie DR, Simpson JI (1997) Association between dendritic lamellar bodies and complex spike synchrony in the olivocerebellar system. J Neurophysiol 77:1747-1758. Medline

De Zeeuw CI, Hoebeek FE, Schonewille M (2008) Causes and consequences of oscillations in the cerebellar cortex. Neuron 58:655-658. CrossRef Medline

De Zeeuw CI, Hoebeek FE, Bosman LW, Schonewille M, Witter L, Koekkoek SK (2011) Spatiotemporal firing patterns in the cerebellum. Nat Rev Neurosci 12:327-344. CrossRef Medline

Dizon MJ, Khodakhah K (2011) The role of interneurons in shaping Purkinje cell responses in the cerebellar cortex. J Neurosci 31:10463-10473. CrossRef Medline

Ebner TJ, Bloedel JR (1981) Correlation between activity of Purkinje cells and its modification by natural peripheral stimuli. J Neurophysiol 45: 948-961. Medline

Ebner TJ, Hewitt AL, Popa LS (2011) What features of limb movements are encoded in the discharge of cerebellar neurons? Cerebellum 10:683-693. CrossRef Medline

Ebner TJ, Wang X, Gao W, Cramer SW, Chen G (2012) Parasagittal zones in the cerebellar cortex differ in excitability, information processing, and synaptic plasticity. Cerebellum 11:418-419. CrossRef Medline

Eccles JC (1973) The cerebellum as a computer: patterns in space and time. J Physiol 229:1-32. Medline

Fatemi SH, Aldinger KA, Ashwood P, Bauman ML, Blaha CD, Blatt GJ, Chauhan A, Chauhan V, Dager SR, Dickson PE, Estes AM, Goldowitz D, Heck DH, Kemper TL, King BH, Martin LA, Millen KJ, Mittleman G, Mosconi MW, Persico AM, et al. (2012) Consensus paper: pathological role of the cerebellum in autism. Cerebellum 11:777-807. CrossRef Medline

Feldman JL, Mitchell GS, Nattie EE (2003) Breathing: rhythmicity, plasticity, chemosensitivity. Annu Rev Neurosci 26:239-266. CrossRef Medline

Fortier PA, Kalaska JF, Smith AM (1989) Cerebellar neuronal activity related to whole-arm reaching movements in the monkey. J Neurophysiol 62:198-211. Medline

Galliano E, Gao Z, Schonewille M, Todorov B, Simons E, Pop AS, D’Angelo E, van den Maagdenberg AM, Hoebeek FE, De Zeeuw CI (2013) Silencing the majority of cerebellar granule cells uncovers their essential role in 
motor learning and consolidation. Cell Rep 3:1239-1251. CrossRef Medline

Gao Z, van Beugen BJ, De Zeeuw CI (2012) Distributed synergistic plasticity and cerebellar learning. Nat Rev Neurosci 13:619-635. CrossRef Medline

Gauck V, Jaeger D (2000) The control of rate and timing of spikes in the deep cerebellar nuclei by inhibition. J Neurosci 20:3006-3016. Medline

Graham DJ, Wylie DR (2012) Zebrin-immunopositive and -immunonegative stripe pairs represent functional units in the pigeon vestibulocerebellum. J Neurosci 32:12769-12779. CrossRef Medline

Harvey RJ, Porter R, Rawson JA (1977) The natural discharges of Purkinje cells in paravermal regions of lobules V and VI of the monkey's cerebellum. J Physiol 271:515-536. Medline

Hayar A, Bryant JL, Boughter JD, Heck DH (2006) A low-cost solution to measure mouse licking in an electrophysiological setup with a standard analog-to-digital converter. J Neurosci Methods 2:203-207. CrossRef Medline

Heck DH, Howell JW (2013) Prefrontal cortical-cerebellar interaction deficits in autism spectrum disorders. Autism 4:1. CrossRef

Heck DH, Thach WT, Keating JG (2007) On-beam synchrony in the cerebellum as the mechanism for the timing and coordination of movement. Proc Natl Acad Sci U S A 104:7658-7663. CrossRef Medline

Heck DH, Zhao Y, Roy S, LeDoux MS, Reiter LT (2008) Analysis of cerebellar function in Ube3a deficient mice reveals novel genotype specific behaviors. Hum Mol Gen 17:2181-2189. CrossRef Medline

Heck DH, Gu W, Cao Y, Qi S, Lacaria M, Lupski JR (2012) Opposing phenotypes in mice with Smith-Magenis deletion and Potocki-Lupski duplication syndromes suggest gene dosage effects on fluid consumption behavior. Am J Med Genet 158A:2807-2814. CrossRef Medline

Hoebeek FE, Witter L, Ruigrok TJ, De Zeeuw CI (2010) Differential olivocerebellar cortical control of rebound activity in the cerebellar nuclei. Proc Natl Acad Sci U S A 107:8410-8415. CrossRef Medline

Holdefer RN, Miller LE, Chen LL, Houk JC (2000) Functional connectivity between cerebellum and primary motor cortex in the awake monkey. J Neurophysiol 84:585-590. Medline

Ito M (1984) The cerebellum and neural control. New York: Raven.

Ito M, Yoshida M (1966) The origin of cerebellar-induced inhibition of Deiters neurons: I. Monosynaptic initiation of the inhibitory postynatic potentials. Exp Brain Res 2:330-349. Medline

Ito M, Yoshida M, Obata K, Kawai N, Udo M (1970) Inhibitory control of intracerebellar nuclei by the Purkinje cell axons. Exp Brain Res 10:64-80. CrossRef Medline

Ito M, Yoshida M, Obata K (1964) Monosynaptic inhibition of the intracerebellar nuclei induced from the cerebellar cortex. Experientia 20:575576. CrossRef Medline

Kim CH, Oh SH, Lee JH, Chang SO, Kim J, Kim SJ (2012) Lobule-specific membrane excitability of cerebellar Purkinje cells. J Physiol 590:273-288. CrossRef Medline

Koziol LF, Budding DE, Chidekel D (2012) From movement to thought: executive function, embodied cognition, and the cerebellum. Cerebellum 11:505-525. CrossRef Medline

Lu L, Cao Y, Tokita K, Heck DH, Boughter JD Jr (2013) Medial cerebellar nuclear projections and activity patterns link cerebellar output to orofacial and respiratory behavior. Front Neural Circuits 7:56. CrossRef Medline

MacKay WA, Murphy JT (1976) Integrative versus delay line characteristics of cerebellar cortex. Can J Neurol Sci 3:85-97. Medline

McDevitt CJ, Ebner TJ, Bloedel JR (1987) Relationships between simultaneously recorded Purkine cells and cerebellar nuclear neurons. Brain Res 425:1-13. CrossRef Medline

Medina JF, Lisberger SG (2007) Variation, signal, and noise in cerebellar sensory-motor processing for smooth-pursuit eye movements. J Neurosci 27:6832-6842. CrossRef Medline

Mittleman G, Goldowitz D, Heck DH, Blaha CD (2008) Cerebellar modulation of frontal cortex dopamine efflux in mice: relevance to autism and schizophrenia. Synapse 62:544-550. CrossRef Medline

Oscarsson O (1979) Functional units of the cerebellum-sagittal zones and microzones. Trends Neurosci 2:143-145. CrossRef

Palay SL, Chan-Palay V (1974) Cerebellar cortex: cytology and organization. Berlin: Springer.

Pasalar S, Roitman AV, Durfee WK, Ebner TJ (2006) Force field effects on cerebellar Purkinje cell discharge with implications for internal models. Nat Neurosci 9:1404-1411. CrossRef Medline
Person AL, Raman IM (2010) Deactivation of L-type Ca current by inhibition controls LTP at excitatory synapses in the cerebellar nuclei. Neuron 66:550-559. CrossRef Medline

Person AL, Raman IM (2012) Purkinje neuron synchrony elicits timelocked spiking in the cerebellar nuclei. Nature 481:502-505. CrossRef Medline

Popa LS, Hewitt AL, Ebner TJ (2012) Predictive and feedback performance errors are signaled in the simple spike discharge of individual Purkinje cells. J Neurosci 32:15345-15358. CrossRef Medline

Popa LS, Hewitt AL, Ebner TJ (2013) Purkinje cell simple spike discharge encodes error signals consistent with a forward internal model. Cerebellum 12:331-333. CrossRef Medline

Pugh JR, Raman IM (2009) Nothing can be coincidence: synaptic inhibition and plasticity in the cerebellar nuclei. Trends Neurosci 32:170-177. CrossRef Medline

Raman IM, Gustafson AE, Padgett D (2000) Ionic currents and spontaneous firing in neurons isolated from the cerebellar nuclei. J Neurosci 20: 9004-9016. Medline

Robinson FR, Fuchs AF (2001) The role of the cerebellum in voluntary eye movements. Annu Rev Neurosci 24:981-1004. CrossRef Medline

Rogers TD, Dickson PE, Heck DH, Goldowitz D, Mittleman G, Blaha CD (2011) Connecting the dots of the cerebro-cerebellar role in cognitive function: neuronal pathways for cerebellar modulation of dopamine release in the prefrontal cortex. Synapse 65:1204-1212. CrossRef Medline

Rogers TD, Dickson PE, McKimm E, Heck DH, Goldowitz D, Blaha CD, Mittleman G (2013) Reorganization of circuits underlying cerebellar modulation of prefrontal cortical dopamine in mouse models of autism spectrum disorder. Cerebellum 12:547-556. CrossRef Medline

Roitman AV, Pasalar S, Johnson MT, Ebner TJ (2005) Position, direction of movement, and speed tuning of cerebellar Purkinje cells during circular manual tracking in monkey. J Neurosci 25:9244-9257. CrossRef Medline

Roy S, Zhao Y, Allensworth M, Farook MF, LeDoux MS, Reiter LT, Heck DH (2011) Comprehensive motor testing in Fmr1-KO mice exposes temporal defects in oromotor coordination. Behav Neurosci 125:962-969. CrossRef Medline

Schmahmann JD, Caplan D (2006) Cognition, emotion and the cerebellum. Brain 129:290-292. CrossRef Medline

Schonewille M, Belmeguenai A, Koekkoek SK, Houtman SH, Boele HJ, van Beugen BJ, Gao Z, Badura A, Ohtsuki G, Amerika WE, Hosy E, Hoebeek FE, Elgersma Y, Hansel C, De Zeeuw CI (2010) Purkinje cell-specific knockout of the protein phosphatase PP2B impairs potentiation and cerebellar motor learning. Neuron 67:618-628. CrossRef Medline

Schonewille M, Gao Z, Boele HJ, Veloz MF, Amerika WE, Simek AA, De Jeu MT, Steinberg JP, Takamiya K, Hoebeek FE, Linden DJ, Huganir RL, De Zeeuw CI (2011) Reevaluating the role of LTD in cerebellar motor learning. Neuron 70:43-50. CrossRef Medline

Shidara M, Kawano K, Gomi H, Kawato M (1993) Inverse-dynamics model eye movement control by Purkinje cells in the cerebellum. Nature 365: 50-52. CrossRef Medline

Shin SL, De Schutter E (2006) Dynamic synchronization of Purkinje cell simple spikes. J Neurophysiol 96:3485-3491. CrossRef Medline

Shinoda Y, Sugiuchi Y, Futami T, Izawa R (1992) Axon collaterals of mossy fibers from the pontine nucleus in the cerebellar dentate nucleus. J Neurophysiol 67:547-560. Medline

Smith AM, Dugas C, Fortier P, Kalaska J, Picard N (1993) Comparing cerebellar and motor cortical activity in reaching and grasping. Can J Neurol Sci 20 [Suppl 3]:S53-S61.

Steuber V, Schultheiss NW, Silver RA, De Schutter E, Jaeger D (2011) Determinants of synaptic integration and heterogeneity in rebound firing explored with data-driven models of deep cerebellar nucleus cells. J Comput Neurosci 30:633-658. CrossRef Medline

Stoodley CJ (2011) The cerebellum and cognition: evidence from functional imaging studies. Cerebellum 11:362-365. CrossRef Medline

Strata P (ed.) (1989) The olivocerebellar system in motor-control. Berlin: Springer.

Sugihara I, Marshall SP, Lang EJ (2007) Relationship of complex spike synchrony bands and climbing fiber projection determined by reference to aldolase C compartments in crus IIa of the rat cerebellar cortex. J Comp Neurol 501:13-29. CrossRef Medline

Ten Brinke M, Boele H, De Zeeuw CI (2013) Combining single unit electrophysiology and eyeblink conditioning in (transgenic) mice to elucidate 
molecular mechanisms underlying cerebellar learning. Abstract, Gordon Conference on Cerebellum. Aug. 11-16, 2013, New London, NH.

Thach WT (1968) Discharge of cerebellar Purkinje and nuclear neurons during rapidly alternating arm movements in the monkey. J Neurophysiol 31:785-797. Medline

Thach WT (1970a) Discharge of cerebellar neurons related to two maintained postures and two prompt movements: II. Purkinje cell output and input. J Neurophysiol 33:537-547. Medline

Thach WT (1970b) Discharge of derebellar neurons related to two maintained postures and two prompt movements: I. Nuclear cell output. J Neurophysiol 33:527-536. Medline

Thach WT (1972) Cerebellar output: properties, synthesis and uses. Brain Res 40:89-102. CrossRef Medline

Thach WT (1978) Correlation of neural discharge with pattern and force of muscular activity, joint position, and direction of intended next movement in motor cortex and cerebellum. J Neurophysiol 41:654-676. Medline

Thier P, Dicke PW, Haas R, Barash S (2000) Encoding of movement time by populations of cerebellar Purkinje cells. Nature 405:72-76. CrossRef Medline

Travers JB, Dinardo LA, Karimnamazi H (1997) Motor and premotor mechanisms of licking. Neurosci Biobehav Rev 21:631-647. CrossRef Medline

Van Der Giessen RS, Koekkoek SK, van Dorp S, De Gruijl JR, Cupido A, Khosrovani S, Dortland B, Wellershaus K, Degen J, Deuchars J, Fuchs EC, Monyer H, Willecke K, De Jeu MT, De Zeeuw CI (2008) Role of olivary electrical coupling in cerebellar motor learning. Neuron 58:599-612. CrossRef Medline

Voogd J, Barmack NH (2006) Oculomotor cerebellum. Prog Brain Res 151: 231-268. CrossRef Medline

Voogd J, Schraa-Tam CK, van der Geest JN, De Zeeuw CI (2012) Visuomo- tor cerebellum in human and nonhuman primates. Cerebellum 11:392410. CrossRef Medline

Wadiche JI, Jahr CE (2005) Patterned expression of Purkinje cell glutamate transporters controls synaptic plasticity. Nat Neurosci 8:1329-1334. CrossRef Medline

Walter JT, Khodakhah K (2009) The advantages of linear information processing for cerebellar computation. Proc Natl Acad Sci U S A 106:44714476. CrossRef Medline

Weijnen JA, Wouters J, van Hest JM (1984) Interaction between licking and swallowing in the drinking rat. Brain Behav Evol 25:117-127. CrossRef Medline

Welsh JP, Lang EJ, Suglhara I, Llinás R (1995) Dynamic organization of motor control within the olivocerebellar system. Nature 374:453-457. CrossRef Medline

Welzl H, Bures J (1977) Lick-synchronized breathing in rats. Physiol Behav 18:751-753. CrossRef Medline

Wise AK, Cerminara NL, Marple-Horvat DE, Apps R (2010) Mechanisms of synchronous activity in cerebellar Purkinje cells. J Physiol 588:23732390. CrossRef Medline

Witter L, Canto CB, Hoogland TM, de Gruijl JR, De Zeeuw CI (2013) Strength and timing of motor responses mediated by rebound firing in the cerebellar nuclei after Purkinje cell activation. Front Neural Circuits 7:133. CrossRef Medline

Wulff $\mathrm{P}$, Schonewille $\mathrm{M}$, Renzi M, Viltono L, Sassoè-Pognetto M, Badura A, Gao Z, Hoebeek FE, van Dorp S, Wisden W, Farrant M, De Zeeuw CI (2009) Synaptic inhibition of Purkinje cells mediates consolidation of vestibulo-cerebellar motor learning. Nat Neurosci 12:1042-1049. CrossRef Medline

Zhou H, Lin Z, Voges K, Gao Z, Ruigrok TJ, Hoebeek FE, De Zeeuw CI, Schonewille M (2013) Cerebellar modules operate at different frequencies. Abstract, Gordon Conference on Cerebellum, Aug. 11-16, 2013, New London, NH. 